\title{
Analysis Of The Effect Of Product Quality, Product Style, Product Price, Brand Image, Service Quality And Store Environment Factors On Brand Loyalty On Uniqlo Customers In Surabaya
}

\author{
Wenny Geovania ${ }^{\mathrm{a}}$, Ronald ${ }^{\mathrm{b}}$, Amelia $^{\mathrm{c} *}$ \\ awennygeovanii@gmail.com \\ ${ }^{a}$ Master of Management Student at Pelita Harapan University, Surabaya 60234, Indonesia \\ ${ }^{b, c}$ The Lecturer of Master of Management at Pelita Harapan University, Surabaya 60234, Indonesia
}

\begin{abstract}
The development of the fashion world in Indonesia has also increased quite rapidly. Fashion is any fashion of clothing or accessories that is popular in a certain place within a certain period of time too. The fastest growing fashion is clothes, this is due to the very fast changing of clothes. One of the fashion items that enter shopping centers in Surabaya is Uniqlo. Uniqlo is a fashion retailer from Japan that offers causal clothing for anyone. Uniqlo products have a function and are made of good materials, such as women's jeans which are elastic so they are suitable for daily activities. The purpose of this study was to determine the effect of product quality, product style, product price, brand image, service quality and store environment of brand loyalty. The expected benefits of this research is to increase the repertoire of knowledge in the field of management, especially how large the influence of product quality, product style, product price, brand image, service quality and store environment so as to increase Brand Loyalty for Uniqlo customers in Surabaya. This study is causal. The method used is quantitative methods of processing the data using AMOS. Data was collected by distributing questionnaires to 125 respondents with the characteristics of male and female respondents aged 18-60 years, and has visited Uniqlo at least 1 year.The results showed that Product Quality with regression coefficient of 0.369; Product Style with regression coefficient of 0.277 , Product Price with regression coefficient of 0.635 , and Service Quality with regression coefficient of 0.238 , positive and significantly affect Brand Loyalty; Brand Image with regression coefficient of 0.015 and Store Environment with regression coefficient of 0.021, positive and not significantly affect Brand Loyalty
\end{abstract}

Keywords: product quality, product style, product price, brand image, service quality, store environment, brand loyalty

\section{Introduction}

Growth in Indonesia for clothing needs is growing very rapidly. So that it makes the need for clothing which is commonly referred to as Fashion a more important need when compared to primary needs. One of the fashion trends that continues to grow is ready-to-wear clothing, so that many entrepreneurs build a fashion business with the concept of fast fashion which has a fast fashion change with appropriate production costs. (https://www.kompasiana.com/, downloaded on 22 May 2020)

The development of the fashion world in Indonesia has also increased quite rapidly. This can be proven by the presence of local designers who are increasingly potential, the level of Indonesia's economy is also getting better and various retail industries are also experiencing rapid development. (https://serba-serbi-duniafashion.weebly.com/, downloaded on May 22, 2020). 
Fashion is any fashion of clothing or accessories that is popular in a certain place within a certain period of time too. The word fashion can also be used in various meanings, such as beauty and style or style. Where the beauty and style or style can continue to change by following the times. Apart from that, fashion can also be used to explain a person's popularity. For example, in the middle and upper class, especially celebrities and celebrities who always spend more money to buy the latest clothes from a brand just to show their popularity. (https://www.kompasiana.com/, downloaded on 22 May 2020).

In the world of fashion, the fastest growing fashion is clothes, this is due to the very fast changing of clothes and clothes are one of the most purchased items by the public when compared to other products such as bags and shoes. Everyone must have more clothes than bags and shoes. And also with the existence of technology that is increasingly developing, making Indonesian people more familiar with the world of fashion so that the development of the fashion world in Indonesia is much influenced by western culture or foreign culture. (https: // sundries-world-fashion.weebly.com/, downloaded on May 22, 2020).

According to the East Java APPBI chairman, the results of fashion retail sales from abroad managed to increase by 8-15 percent in Surabaya throughout 2018 when compared to the previous year. The East Java APPBI chairman also said that many foreign investors in the fashion industry are eyeing the Surabaya market, this is because the Surabaya people's consumption of branded clothes is increasing because they continue to follow the existing trends. In addition, it is also caused by the growing purchasing power of people in the middle segment, so that an increasing number of fashion tenants with foreign brands enter shopping centers in Surabaya, one of which is Uniqlo. (https://radarsurabaya.jawapos.com/, downloaded on 22 May 2020).
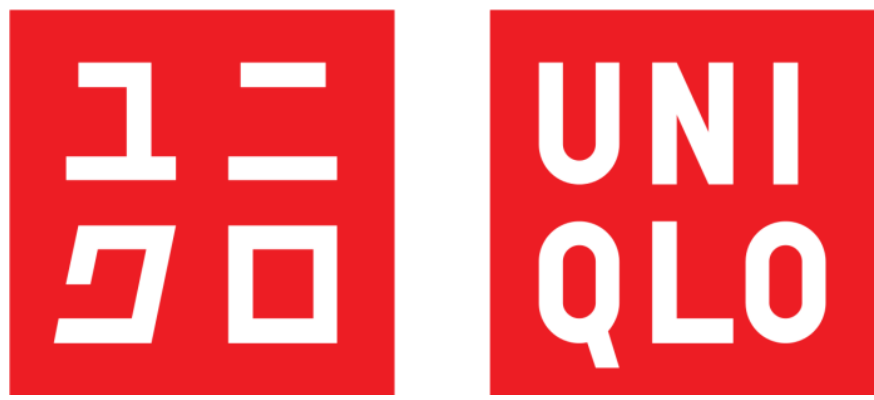

Figure 1.1 Uniqlo Co., Ltd logo.

Source: https://www.google.co.id/, downloaded on 22 May 2020

The name Uniqlo comes from the name of the first shop named Unique Clothing Warehouse opened by Tadashi Yanai in Hiroshima City, Hiroshima Prefecture on June 2, 1984. Uniqlo is a Japanese fashion retailer that offers causal clothing to anyone and is one of the fashion retailers entering Indonesia, (can be seen in Figure 1.1 Uniqlo Co., Ltd logo). Uniqlo first entered Surabaya on September 1, 2017. (http://abyadscreenprinting.com/, downloaded on May 22, 2020)

Uniqlo does not only sell products for women, but Uniqlo also sells products for men and children which are almost equal in number. Uniqlo products have functions and are made from good materials. For example, such as women's jeans which are made of elastic and can be bent so that they are suitable for daily activities. Uniqlo also produces products made from airism, so it is very suitable for summer and suits the very hot weather in Surabaya. Uniqlo also released a Heattech product that is suitable for use in winter, because this product warms the body. Uniqlo also provides products that can be used for leisure and according to consumer needs. (https://bisnisnasional.com/, downloaded on 22 May 2020).

This study also discusses the factors that affect brand loyalty. To see the factors that influence brand loyalty based on several replicated and compiled journals, we will examine whether the variables of product 
quality, product style, product price, brand image, service quality and store environment have a significant effect on brand loyalty with gender moderation in Uniqlo customers in Surabaya

\section{Litterature Review}

\subsection{Theories and Hypotheses}

\subsubsection{Product Quality}

According to Anwar (2015) product quality is the quality of a product that consumers can accept according to consumer wants and needs. According to Kotler \& Armstrong (2012) product quality, namely the quality of a product or service that supports the ability to satisfy, express, and imply customer needs. Research results are supported by (Abdullah 2015), emphasizing that product quality plays an important role in brand loyalty by influencing consumer purchasing behavior, because it provides consumers with relatively good reasons to buy from certain brands (Abdullah 2015).

H1: Product Quality has a significant influence on Brand Loyalty.

\subsubsection{Product Style}

According to Kotler and Keller (2009) product style is the style of a product that affects the appearance, taste and function of the product based on consumer needs. According to Sutojo (2009) product style is a style of product that differentiates the products produced by the company from those of competitors. The results of research conducted by Horvath (2001), confirm that product style has a significant relationship to brand loyalty. This is because product style plays an important role in building brand personality and creating product image characteristics that make consumers loyal to the brand.

H2: Product Style has a significant influence on Brand Loyalty.

\subsubsection{Product Price}

The product price is the amount of money that consumers must spend to buy a product or service produced by a company (Philip Kotler, 2012). According to Guntur (2010) the product price is the amount of money that is billed for a product and service or the amount of value exchanged by customers to benefit from owning or using a product for services. The results of research conducted by Fundera (2017) confirm that product price has a significant relationship to brand loyalty.

H3: Product price has a significant influence on Brand Loyalty.

\subsubsection{Brand Image}

According to Tjiptono (2015), brand image is a description of consumer associations and beliefs in a brand and is always in the minds of consumers. According to Supranto (2011), brand image is what consumers think or feel when consumers hear or see the name of a brand or in essence what consumers have learned about the brand. Muhammad et al., (2013) define a brand as what consumers understand about a brand. brand image can be seen as an attitude body based on the attitude of one group. The results of research conducted by Ming et al., (2011) and Eschet et, al., (2006) found that Brand Image has a positive effect on Brand Loyalty.

H4: Brand Image has a significant influence on Brand Loyalty.

\subsubsection{Service Quality}


Lupiyoadi (2014) states that service quality is any activity or action offered by one person to another, which is basically intangible and does not result in any transfer of ownership. According to Aaker (1992) service quality provides added value for a brand. Good service quality will give consumers a reason to buy a brand and make a difference from other competitors. So it can be said that service quality has a positive effect on brand loyalty. This is in accordance with research conducted by Sahin et al. (2011) and Etemadifard et al. (2013) which states that service quality has a significant effect on brand loyalty.

H5: Service Quality has a significant influence on Brand Loyalty.

\subsubsection{Store Environment}

According to Gillbert (2013), said that the store environment is a combination of physical messages that have been planned or store atmosphere can be described as a change in the purchasing environment planning that produces special emotional effects that can cause consumers to take purchase actions. The results of research conducted by Choi, Heo \& Kim (2012) found that the store environment has a significant relationship with brand loyalty. This is because if the positive quality of the store, which includes location, layout, and interesting stimuli, will affect customer brand loyalty, because the perception of customer satisfaction will encourage him to revisit the store in the future. The results of this study are also supported by Kumar \& Kim (2014) which states that store environments also provide significant opportunities to create and strengthen brand loyalty.

H6: Store Environment has a significant influence on Brand Loyalty

\subsubsection{Brand Loyalty}

According to Mabkhot et, al., (2016), brand loyalty is loyalty to a brand that is considered a marketing idea, which is used as an effort to build long-term relationships with consumers. According to Sudaryono, (2016) defines brand loyalty as a positive attitude of consumers towards a brand, and consumers have a strong desire to repurchase the same product now and in the future. According to Kotller and Keller (2016) brand loyalty is a deeply held commitment to buy or support back preferred products or services in the future even though the influence of situations and marketing efforts has the potential to cause customers to switch. According to Schiffman \& Wisenblit (2015) brand loyalty is consumer learning about purchasing a brand where consumers do not see other available alternatives.

\subsection{Research Model}




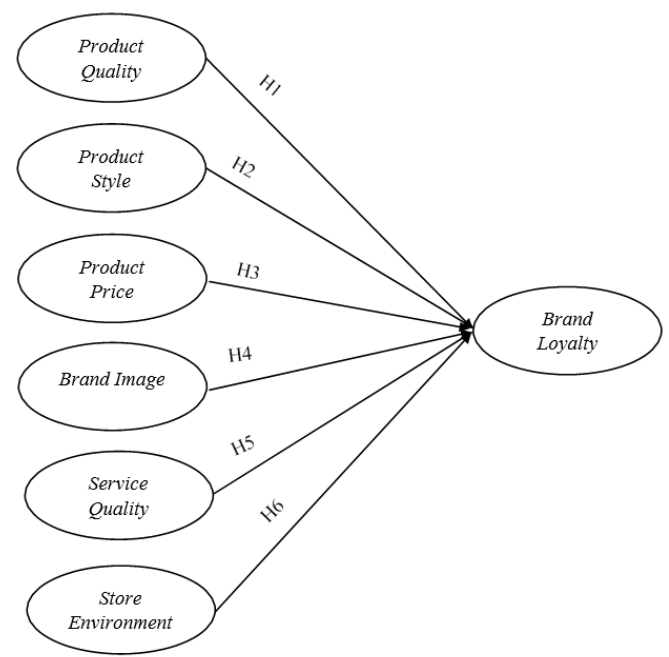

Figure 2.1: The Framework of Research Model

\section{Research Methods}

This type of research is causality research because the research will develop a previous research model to test the research hypothesis that is determined based on literature review to answer the problems identified in the previous chapter. The method used in this study will refer to references that can carry out a simultaneous analysis process associated with a multi-variable research model, namely the Structural Equation Model (SEM) using AMOS 22.0 software. This research model is expected to explain the relationship between variables in order to understand the factors that affect the brand loyalty of Uniqlo customers in Surabaya as well as make an implication that the results will approach the requirements of a measurement that will be described through a research design. In this study, the research population is consumers who purchase Uniqlo products in Surabaya. In this study, the method used to take samples is non-probability sampling and snowball sampling and to collect data using a questionnaire method. The non-probability sampling method is used because the population who has bought Uniqlo products is not known for sure. Meanwhile, snowball is used so that the distribution of questionnaires can be done quickly and accurately. According to Sugiyono (2001), Snowball sampling is a technique of determining a sample that is initially small, then the sample is distributed to friends to be sampled and then passed on to other friends until it becomes many. That way, to distribute the questionnaire through the snowball method, it will be distributed to the Pelita Harapan University in Surabaya environment and later friends will help distribute the questionnaire to other people. In accordance with the determined characteristics, by having certain characteristics, namely: (1) Male and Female; (2) Domiciled in the Surabaya area; (3) 18-60 years old; (4) Have purchased Uniqlo products in Surabaya at least 2 times in the last 1 year.

\section{Results and Discussion}

\subsection{Assessment of Measurement Model}

Table 4.1: Regression Weights Full Structural Equation Model 


\begin{tabular}{|c|c|c|c|c|c|c|c|}
\hline & & & Estimate & S.E. & C.R. & $\mathrm{P}$ & Estimate \\
\hline Brand_Loyalty & $<---$ & Product_Quality & 0.346 & 0.124 & 2.8 & 0.005 & 0.369 \\
\hline Brand_Loyalty & $<---$ & Product_Style & 0.321 & 0.135 & 2.382 & 0.017 & 0.277 \\
\hline Brand_Loyalty & $<---$ & Product_Price & 0.432 & 0.102 & 4.247 & $* * *$ & 0.635 \\
\hline Brand_Loyalty & $<---$ & Brand_Image & 0.016 & 0.121 & 0.128 & 0.898 & 0.015 \\
\hline Brand_Loyalty & $<---$ & Service_Quality & 0.164 & 0.081 & 2.035 & 0.042 & 0.238 \\
\hline Brand_Loyalty & $<---$ & Store_Environment & 0.029 & 0.155 & 0.189 & 0.85 & 0.021 \\
\hline $\mathrm{X} 3$ & $<---$ & Product_Quality & 1 & & & & 0.675 \\
\hline $\mathrm{X} 2$ & $<---$ & Product_Quality & 0.667 & 0.191 & 3.497 & **** & 0.506 \\
\hline $\mathrm{X} 1$ & $<--$ & Product_Quality & 0.701 & 0.188 & 3.722 & **** & 0.627 \\
\hline $\mathrm{X} 10$ & $<---$ & Product_Price & 1 & & & & 0.607 \\
\hline X9 & $<---$ & Product_Price & 1.178 & 0.205 & 5.742 & **** & 0.769 \\
\hline X8 & $<---$ & Product_Price & 1.162 & 0.207 & 5.609 & $* * *$ & 0.733 \\
\hline X16 & $<---$ & Service_Quality & 1 & & & & 0.735 \\
\hline $\mathrm{X} 15$ & $<---$ & Service_Quality & 1.046 & 0.149 & 7.031 & $* * *$ & 0.783 \\
\hline X14 & $<---$ & Service_Quality & 0.982 & 0.149 & 6.576 & $* * *$ & 0.66 \\
\hline $\mathrm{X} 13$ & $<---$ & Brand_Image & 1 & & & & 0.704 \\
\hline $\mathrm{X} 12$ & $<---$ & Brand_Image & 0.985 & 0.292 & 3.376 & $* * *$ & 0.519 \\
\hline $\mathrm{X} 11$ & $<---$ & Brand_Image & 1.009 & 0.299 & 3.374 & $* * *$ & 0.6 \\
\hline X6 & $<---$ & Product_Style & 1 & & & & 0.663 \\
\hline $\mathrm{X} 5$ & $<---$ & Product_Style & 1.024 & 0.328 & 3.126 & 0.002 & 0.679 \\
\hline $\mathrm{X} 4$ & $<---$ & Product_Style & 0.633 & 0.174 & 3.636 & $* * *$ & 0.46 \\
\hline $\mathrm{X} 20$ & $<---$ & Store_Environment & 1 & & & & 0.415 \\
\hline X19 & $<---$ & Store_Environment & 1.542 & 0.505 & 3.054 & 0.002 & 0.825 \\
\hline $\mathrm{X} 18$ & $<--$ & Store_Environment & 1.031 & 0.322 & 3.2 & 0.001 & 0.466 \\
\hline $\mathrm{X} 7$ & $<---$ & Product_Style & 0.626 & 0.211 & 2.961 & 0.003 & 0.462 \\
\hline $\mathrm{X} 17$ & $<---$ & Service_Quality & 0.718 & 0.119 & 6.06 & $* * *$ & 0.627 \\
\hline $\mathrm{X} 21$ & $<---$ & Store_Environment & 1.425 & 0.416 & 3.423 & **** & 0.5 \\
\hline Y1 & $<---$ & Brand_Loyalty & 1 & & & & 0.647 \\
\hline Y2 & $<---$ & Brand_Loyalty & 1.007 & 0.168 & 5.984 & **** & 0.617 \\
\hline Y3 & $<---$ & Brand_Loyalty & 0.86 & 0.154 & 5.568 & **** & 0.587 \\
\hline Y4 & $<--$ & Brand_Loyalty & 1.464 & 0.26 & 5.637 & **** & 0.658 \\
\hline
\end{tabular}

C.R. for each relationship between the variables tested is shown in table 4.1. The causal relationship that occurs between brand image variables on Brand loyalty, store environment on brand loyalty has an insignificant relationship because the C.R value is above 2.00 . 
Table 4.2: Summary of Testing Results.

\begin{tabular}{|l|l|}
\hline Hypotheses & Analysis \\
\hline H1: product quality has a significant effect on brand loyalty & Accepted \\
\hline H2: product style has a significant effect on brand loyalty & Accepted \\
\hline H3: product price has a significant effect on brand loyalty & Accepted \\
\hline H4: brand image has a significant effect on brand loyalty & Rejected \\
\hline H5: service quality has a significant effect on brand loyalty & Accepted \\
\hline H6: store environment has a significant effect on brand loyalty & Rejected \\
\hline
\end{tabular}

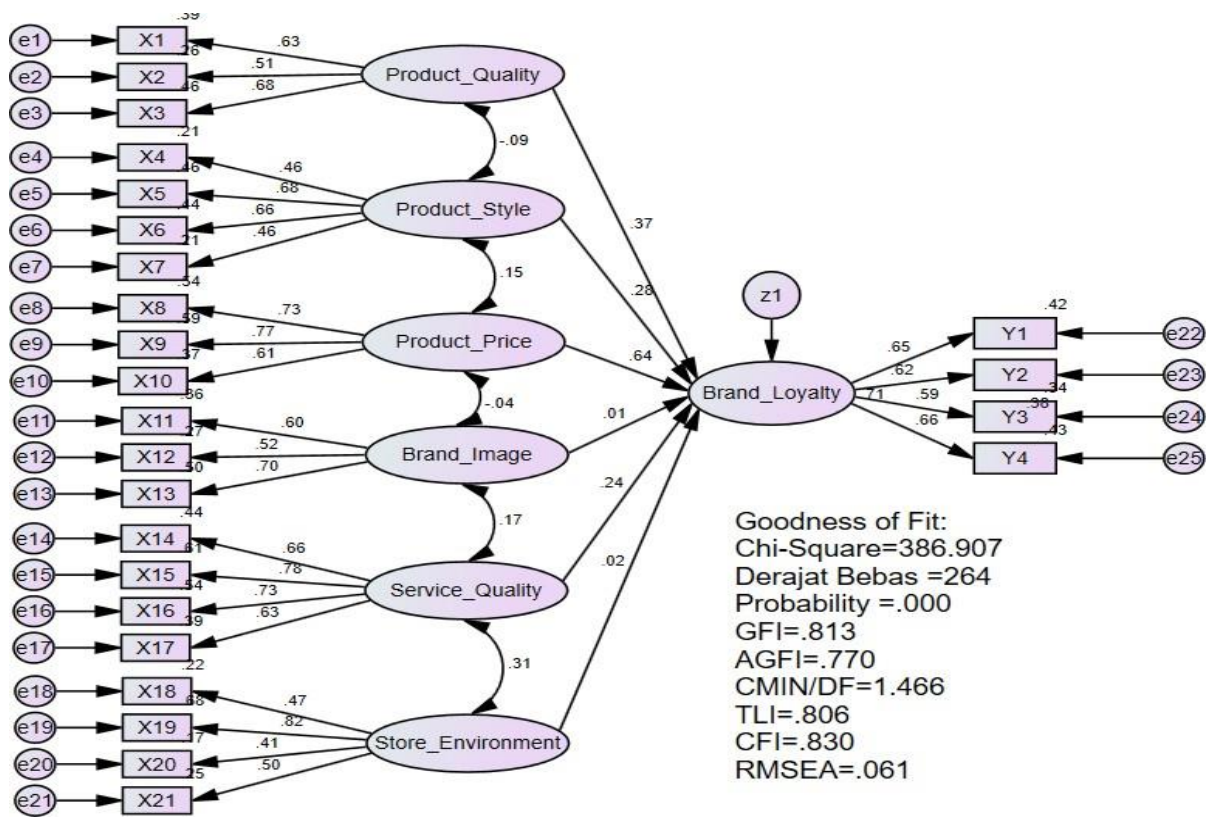

Figure 4.1: The Framework of Analysis Result

\subsection{Discussion}

The results of data processing using AMOS 22.0 software show the six hypotheses proposed in this study. These results can be described as follows, the variable product quality has a significant effect on brand loyalty with a regression coefficient of 0.369 and C.R. 2,800; product style variable has a significant effect on brand loyalty with a regression coefficient of 0.277 and C.R. amounting to 2,382; product price variable has a significant effect on brand loyalty with a regression coefficient of 0.635 and C.R. amounting to 4,247; brand image variable has no significant effect on brand loyalty with a regression coefficient of 0.015 and C.R. equal to 0.128 ; service quality variable has a significant effect on brand loyalty with a regression coefficient of 0.238 and C.R. amounting to 2,035; store environment variable has no significant effect on brand loyalty with a regression coefficient of 0.021 and C.R. amounting to 0.189 . Based on the results of the existing regression coefficients, it can be seen that the effect of product price on brand loyalty has the greatest effect $(0.635)$, then the second largest effect is product quality on brand loyalty (0.369), the third largest effect is product style on brand loyalty (0.277) and the lowest influence is brand image on brand loyalty $(0.015)$. 


\subsubsection{The effect of product quality on brand loyalty}

Product quality variable has a significant positive effect on brand loyalty with a regression coefficient of 0.369 with a C.R. 2,800. this is because according to customers, Uniqlo has products with comfortable and quality materials and also uniqlo has many attractive color choices. One of them is Uniqlo which has denim products with fibers that are $20 \%$ lighter than the fibers found in regular denim. So that the resulting denim is very light and feels comfortable on the skin, flexible, absorbs sweat and is suitable for the season or hot air and makes this product different from other brands, thus making Uniqlo customers even more interested and making repeat purchases of uniqlo products.

\subsubsection{The effect of product style on brand loyalty}

Product style variable has a significant positive effect on brand loyalty with a regression coefficient of 0.277 with a C.R. 2,382. This is because the products provided by Uniqlo have a cool, trendy and fashionable design. Uniqlo also provides products that have a collection of different styles from other products such as the Uniqlo collection that uses technological elements, namely HeatTech, where the body will still feel warm during winter even though the fabric is thin and also has a fashionable design. Other technologies are AIRims where the inner fabric feels soft so it is easier to dry, UV Cut which is a material designed to prevent 90 percent of sunlight and the last one is LifeWear, which is a combination of casual clothes with sportswear. Thus increasing customer loyalty to Uniqlo products.

\subsubsection{The effect of product price on brand loyalty}

Product price variable has a significant positive effect on brand loyalty with a regression coefficient of 0.635 with a C.R. 4,247. product price has the greatest influence on brand loyalty. This is because customers feel that Uniqlo products have relatively affordable and best prices with high quality products and comfortable materials. Uniqlo also has attractive discounts that make Uniqlo customers even more interested in shopping at Uniqlo.

\subsubsection{The effect of brand image on brand loyalty}

Brand image variable has a positive but not significant effect on brand loyalty with a regression coefficient value of 0.015 with a C.R. 0.128. This is because Uniqlo has many similar competitors who have bigger names and are also more famous for the same product quality, so that the customer view of Uniqlo is not as good as other competitors.

\subsubsection{The effect of service quality on brand loyalty}

The service quality variable has a significant positive effect on brand loyalty with a regression coefficient of 0.238 with a C.R. 2,035. This is because customers feel that the appearance of Uniqlo employees looks neat and customers also feel that Uniqlo employees are friendly and master the products offered such as the availability of clothes stocks and help customers find the desired product so that customers feel Uniqlo has good service quality. ultimately affects Uniqlo brand loyalty.

\subsubsection{The effect of store environment on brand loyalty}

Store environment variable has a positive and insignificant effect on brand loyalty with a regression coefficient value of 0.021 with a C.R. 0.189. This is because the Uniqlo store location has an affordable location with an attractive interior design and pleasant colors so that customers feel that Uniqlo has a comfortable environment and also that Uniqlo has the same environmental design as other competitors so that it does not have an effect on increasing Uniqlo customer loyalty. 


\section{Conclusion}

This model was developed in the context of the Uniqlo Brand Loyalty research in Surabaya. This research model is formed from the influence relationship between product quality, product style, product price, brand image, service quality and store environment on brand loyalty. The formulation of the problem in this study is whether product quality variables have a significant effect on brand loyalty, product style variables have a significant effect on brand loyalty, product price has a significant effect on brand loyalty, brand image has a significant effect on brand loyalty, service quality has a significant effect on brand loyalty and variables. store environment has a significant effect on brand loyalty. Based on the data processing carried out, the final result is that of the 6 proposed hypotheses, 4 hypotheses are accepted and 2 hypotheses are rejected

\subsection{Managerial Implications}

Table 5.1: Managerial Implications

\begin{tabular}{|c|c|}
\hline Current Research & Managerial Implications \\
\hline $\begin{array}{l}\text { Product Quality is one } \\
\text { element that is the focus in } \\
\text { the process of increasing } \\
\text { Brand Loyalty }\end{array}$ & $\begin{array}{l}\text { - improve the quality of its products with materials that are more } \\
\text { comfortable and safe to use for both small children and adults } \\
\text { - increase the thickness of the t-shirt material by using a comfortable } \\
\text { cottoncombed } 24 \text { s type fabric } \\
\text { - maintain product color choices on Uniqlo } \\
\text { - maintain the quality of the products that have been used }\end{array}$ \\
\hline $\begin{array}{l}\text { Product Style is one of the } \\
\text { elements that is the focus in } \\
\text { the process of increasing } \\
\text { Brand Loyalty }\end{array}$ & $\begin{array}{l}\text { - improve Uniqlo designs in accordance with the times } \\
\text { - maintains the Uniqlo design made of technology } \\
\text { - Maintaining styles from Uniqlo such as Heatech, AIRims, UV CUT and } \\
\text { LifeWear }\end{array}$ \\
\hline $\begin{array}{l}\text { Product Price is one of the } \\
\text { elements that is the focus in } \\
\text { the process of increasing } \\
\text { Brand Loyalty }\end{array}$ & $\begin{array}{l}\text { - } \text { keep product prices affordable } \\
\text { - maintains its current price with good product quality } \\
\text { - } \text { provide many attractive discounts }\end{array}$ \\
\hline $\begin{array}{l}\text { Brand Image is one of the } \\
\text { elements that is the focus in } \\
\text { the process of increasing } \\
\text { Brand Loyalty }\end{array}$ & $\begin{array}{l}\text { - maintain its brand so that it remains trusted by the customer } \\
\text { - do promotions using artists, celebrities or well-known athletes as brand } \\
\text { ambassadors } \\
\text { - maintain the quality of its products }\end{array}$ \\
\hline $\begin{array}{l}\text { Service Quality is one of the } \\
\text { elements that is the focus in } \\
\text { the process of increasing } \\
\text { Brand Loyalty }\end{array}$ & $\begin{array}{l}\text { - improve Uniqlo employee friendliness } \\
\text { - Increase Uniqlo employees to be more familiar with the product. } \\
\text { - maintains the neat appearance of its employees } \\
\text { - maintain morning briefings of Uniqlo employees }\end{array}$ \\
\hline $\begin{array}{l}\text { Store Environment is one of } \\
\text { the elements that is the focus } \\
\text { in the process of increasing } \\
\text { Brand Loyalty }\end{array}$ & $\begin{array}{l}\text { - maintain the interior appearance of the store } \\
\text { - increase the arrangement of the shelves to make it look more neat } \\
\text { - maintains its affordable location within the mall } \\
\text { - maintain the arrangement of lights in the store which looks elegant }\end{array}$ \\
\hline
\end{tabular}

Based on the results of this study, the main recommendation made for the object of this research is that the price of Uniqlo products must be maintained in accordance with the quality of the products obtained by Uniqlo customers. 


\subsection{Recommendation}

Looking at the results of existing research where there are still many limitations to the research conducted by the author, the recommendations that can be submitted by the author are as follows:

- Seeing the limitations regarding the research object that only takes respondents, namely Uniqlo customers in Surabaya, it is hoped that the next research using the same or modified model can be applied to different objects to get more general results on the factors that affect Brand Loyalty.

- Further research is expected to complement the existing variables in this research so that it can further enhance the understanding of the factors that affect Brand Loyalty, such as advertising, customer satisfaction, and celebrity endorsment.

- Further research can be developed by linking the factors that influence Brand Loyalty based on income levels. Future research could also expand the scope of respondents to be researched, or carry out their research in a different area from the current research. So that further research carried out provides a broad picture of Brand Loyalty.

- In addition, it is also expected to be able to use the Structural Equational Model (SEM) but by using Lisrel software in future research.

\section{References}

Aaker, J.L. (1992). Dimensions of Brand Personality Journal of Marketing Research, Vol. XXXIV (August)

Abdullah, Rohi. 2015. Web Programing is Easy. Jakarta: Elek Media Komputindo

Anwar, I. (2015). Effect of Price and Product Quality on Purchasing Decisions. Journal of Management Science and Research, Vol. 4 No.12 Pages 1-15.

Arikunto, S. 2006. Qualitative Research Methods. Jakarta: Earth Literacy

Armstrong, Kotler 2015, "Marketing an Introducing Pretiece Hall twelfth edition", England: Pearson Education, Inc

Assauri, Sofjan. (2012). Marketing Management. Jakarta: PT Raja Grapindo

Assuncao, J., Faria, S., Carvalho, V. \& Ferreira, P. 2013. The impact of store environment on shopping behavior and loyalty. Studies of Organizational Manage and Sustainability 2 (1): 26-35.

Azwar, Saifuddin. 2007. Research Methods. Student Library: Yogyakarta

Barry Berman, Joel R. Evans, (2001). Eight edition Retail Management, Publisher Intermedia (translation), Jakarta.

Berman, Barny \& Joel R Evans. (2007). Retail Management: A Strategic Approach. Macmillan Publishing Company.

Berman, Barry and Joel R. Evans. (2012). Retail Management, a Strategic Approach, (8th Edition). New Jersey: Pearson

Bitner, M. J. (1992). Servicescapes: The Impact of Physical surroundings on customers and employees. Journal of Marketing. Vol 56 No. 2, pp. 57-71 
Broadbent, S., Bridson, K., Ferkins, L., \& Rentschler, R. (2010). Brand Love, Brand Image and Loyalty in Australian Elite Sport. Australian and New Zealand Marketing Academy, 1-9. Retrieved from http://anzmac2010.org/proceedings/pdf/anzmac10Fina100293.pdf

Brutou and Margaret, 2006 The Psychological of Women: Seventh Edition. USA: Wadsworth

Charles Lamb, W.et.al. 2001. Marketing. First Edition, Salemba Empat: Jakarta.

Choi, W., Heo, J. \& Kim, M. 2012. Effects of physical environment on brand loyalty and moderated effects of brand image. International Proceedings of Economics Development and Research 56 (12): 57-61.

Chong, L., Low, K., Tai, G., Tan, L. \& Tan, S. 2015. Customer loyalty in Malaysian airline industry. Bsc Diss. Universiti Tunku Abdul Rahman, Kuala Lumpur, Malaysia. Available at http://eprints.utar.edu.my/1802/1/BAC-2015-1206820-1.pdf

Churchill, Gilbert A, 2013, Basics of Marketing Research, Jakarta, Publisher: Erlangga.

Cynthia. 2018. Analysis of the Effect of Sales Promotion on Purchasing Decisions at Bellagio Shoe Stores in Manado. EMB Journal, Economic Research, and Accounting. Vol.03, No. 03.

Dimyati, M., Subagio, N.A., 2016. Impact of Service Quality, Price, and Brand on Loyalty with the mediation of Customer Satisfaction on Pos Ekspres in East Java. Mediterranean. J. Soc. Sci. 7, 74.

Durianto, Darmadi, Sugiarto et al, 2004, Brand Equity Trend Strategy to Lead the Market, PT.Gramedia Pustaka Utama: Jakarta.

Effendi M. Guntur. 2010. Transformation of Marketing Management. Jakarta, Sagung Seto.

Ehsan, Muhammad Malik et, al. 2013. Impact of Brand Image, Service Quality and Price on Customer Satisfaction. International Journal of Business and Social Science, Vol. 3, No. 23

Fandy Tjiptono. 2015. Marketing Strategy, 4th Edition, Andi Offset, Yogyakarta

Fandy, Tjiptono and Greforius, Chandra. (2016). Service Marketing (Principles, Application, and Research), Yogyakarta: Andi

Fandy Tjiptono and Gregorius Chandra Dennisa, E. A., \& Santoso, S. B. (2016). Analysis of the Influence of Product Quality, Service Quality and Brand Image on Customer Loyalty through Customer Satisfaction as an Intervening Variable (Study at Cosmedic Beauty Clinic Semarang). Diponegoro Journal Of Management, p. 1 - 13 .. 2007. Service, Quality Satisfaction. Andi Ofset. Yogyakarta

Ferdinand. 2002. Management Research Methods: Research guidelines for Thesis, Thesis, and Management Science Dissertation, Semarang: Diponegoro University Publishing Agency.

Fred R. David, 2009, Strategic Management. Salemba Empat Jakarta

Fundera. 2017. 13 Brand loyalty statistics you need to know to keep your customers coming back. Available at https://www.fundera.com/resources/brand-loyalty-statistics

Giddens, Nancy. (2002). Brand Loyalty. Missouri Value-added Development Center, University of Missouri. 
Hair, J. F., et al. (2007). Multivariate Data Analysis 6 th Edition. New Jersey: Pearson Education Inc.

Hamza Salim, K. 2011. The influence of brand loyalty on cosmestics buying behaviour of UAE female consumers. International Journal of Marketing Studies 3(2) : 123-33

Hartono, dkk. 2011. Paikem. Pekanbaru: zanafa.

Harun Al Rasyid., 2017., Pengaruh Kualitas Layanan dan Pemanfaatan Teknologi Terhadap Kepusan dan Loyalitas Pelanggan Go-Jek, Jurnal Ecodemica, Vol. 1, No. 2, Pp. 210-223.

Hasan, Ali. (2009). Marketing dan Kasus-kasus Pilihan. Yogyakarta: CAPS.

Hasanah, Yatul, Emy. 2009. Studi Mengenai Brand Loyalty Dalam Meningkatkan Brand Equity Kartu Prabayar Gsm Pt.Indosat Kota Semarang. Jurnal Magister Manajemen Program Pasca Sarjana Universitas Diponegoro. Semarang.

Hidayat, A.A.. (2014). Metode penelitian keperawatan dan teknis analisis data. Jakarta : Salemba Medika

Horvath, D. 2001. The role of product design in product related consumer judgements. Unpublished Ph.D. Dissertation, Budapest University of Economic Sciences and Public Administration.

Hussain., Ali. (2015). Effect of Store Atmosphere on Consumer Purchase Intention. International Journal of Marketing Studies, 7 (2). Penerbit Canadian Center of Science and Education

Khoei, R. 2014. Brand loyalty in sportswear in Iran. International Journal of Management, Accounting and Economics 1(1): 52-80.

Kinuthia, L., Mbrurugu, K., Muthomi, H. \& Mwihaki, M. 2012. Factors influencing brand loyalty in sportswear among Kenyan University Students: The Case of Swimmers. Asian Journal of Social Sciences \& Humanities 1(4): 223-231

Kotler Philip, Amstrong Gary. 2013. Prinsip-prinsip Pemasaran, Edisi ke-12. Penerbit Erlangga

Kotler, Phillip, dan Amstrong , Gary. (2014). Principles of Marketing Fourteenth Edition. New Jersey: Pearson Prentice Hall.

Kotler, Philip and Gary Armstrong. 2012. Prinsip-prinsip Pemasaran. Edisi 13. Jilid 1. Jakarta: Erlangga.

Kotler, Philip dan Keller, 2007, Manajemen Pemasaran, Jilid I, Edisi Kedua belas, PT. Indeks, Jakarta.

Kotler, Philip \& Keller, Kevin L. 2016. Marketing Management. 15th Edition, Pearson Education Limited, England, CM20 2JE.

Kotler, Philip Dan Kevin Lane Keller. 2009. Manajemen Pemasaran. Edisi 13 Jilid satu. Erlangga : Jakarta

Kotler, Philip and Kevin Lane Keller, 2016. Marketing Management, 15th Edition, Pearson Education,Inc.

Kotler, Philip and Kevin Lane Keller, (2016): Marketing Management, 15th Edition New Jersey: Pearson Pretice Hall, Inc.

Krishnakumar, K. \& Kavitha, S. 2014. Brand loyalty on footwear. Global Journal For Research Analysis 
International 3(4): 13-16.

Kumar, A. \& Kim, Y. 2014. The store-as-a-brand strategy: The effect of store environment on customer responses. Journal of Retailing and Consumer Services 21(1): 685-695.

Kusumowidagdo, Astrid. 2010. Pengaruh desain atmosfer toko terhadap perilaku belanja. Jurnal Manajemen Bisnis vol 3 (1). 17-32

Lau, Geok Theng dan Sook Han Lee. 2014. Consumer Trust in a Brand and the Link to Brand Loyalty. Journal of Market Focused Management, Vol. 4.

Levy, Michael and Barton Weitz. 2001. Retailing Management. International Edition. McGraw-Hill, New York.

Li, J. 2013. Factors affection customer satisfaction and customer loyalty towards Belle Footwear Company in Lanzhou City, Gansu Province of the People Republic of China. IOSR Journal of Business and Management 14(2): 41-48.

Lin, T. \& Chang, M. 2013. A study of the factors that influence the brand loyalty of Taiwanese adolescents with respect to purchasing mobile. The case of Taichung City. Problems and Perspective in Management 11(2): 86-97

Lovelock dan Wright. 2005. Manajemen Pemasaran Jasa. Jakarta: PT. Indeks.

Lupiyoadi, Rambat. 2014. Manajemen Pemasaran Jasa. Jakarta: Salemba Empat.

Mabkhot, H. A., Salleh, S. M. \& Shaari, H. (2016). The Antecedents of Automobile Brand Loyalty: Evidence from Malaysian. International Review of Management and Marketing 6(3), 596-602

Machfoedz, Mahmud. (2010), “Komunikasi Pemasaran Modern”, Cetakan Pertama, Cakra Ilmu, Yogyakarta.

Marwanto, Aris. 2015. Marketing Sukses. Yogjakarta: KOBIS.

Moenir. Manajemen Pelayanan Umum di Indonesia. Jakarta: PT. Bumi Aksara. 2015

Mowen, J.C., dan Minor, M. 2012. Perilaku Konsumen. Jakarta : Erlangga

Muhammad, D., Seyyed Mohammad, N. \& Nima , B. 2013. Factors and elements influencing brand loyalty: A case study in customers of Khazar gaz in Mazandaran. International Journal of Agriculture and Crop Siences 6(11) : 712-715

Peter J. Paul dan Jerry C. Olson. 2000. Consumer Behavior Jilid II diterjemahkan oleh Damos Sihombing. Jakarta : Erlangga

Rahman et al., 2020. The Influence of Service Quality and Price on Customer Satisfaction: An Empirical Study on Restaurant Services in Khulna Division. Research Journal of Finance and Accounting

Rizan, Mohammad, Basrah Saidani \& Yusiyana Sari. (2012). Pengaruh Brand Image dan Brand trust Terhadap Brand loyalty Teh Botol Sosro Survei Konsumen Teh Botol Sosro Di Food Court Itc Cempaka Mas, Jakarta Timur. Jurnal Riset Manajemen Sains Indonesia (Jrmsi) |Vol. 3, No. 1, 2012. 
Roderick, B. dan Gregory, B. J. 2008. Investigating the service: A customer value perspective. Journal of Business Research. Vol 62. No 7, hal 345-355

Rubini, A. 2010. The role of brand in consumer behaviour: How sneakers have turned into a status symbol. Bsc Diss. Savonia University of Applied Sciences.

Sahin Azize, Cemal Zehin, and Hakam (2011) "The effect of Brand Experinces, Trust and Satisfaction on Building Brand Loyalty: An Empirical Reseach On Global Brand”, Procedia Social and Behavioral Science, Vol 24, pp 1288-1301.

Sari, Yusiana, Mohammad Rizan, Basrah Saidani. (2012). Pengaruh Brand Image dan Brand Trust Terhadap Brand Loyalty Teh Botol Sosro. Jurnal Riset Manajemen Sains

Schiffman, L., Wisenblit, L.,. 2015. Consumer Behavior. Edisi Sebelas. Pearson Education.

Silva, T. S., \& Giraldi, J. D. M. E. (2010). The influence of store image on customer satisfaction: a case study of a shoe store. Brazilian Business Review.

Simamora Henry. 2000. Manajemen Pemasaran internasional. Jilid 1 Edisi Cetak 1, Salemba Empat Jakarta.

Singh, R. 2016. Factors affecting brand loyalty in the footwear industry - A study on Ludhiana District. International Journal of Research-Granthaalayah 4(6): 139-149.

Siswanto Sutojo. 2009. Manajemen Pemasaran. Jakarta: PT.Damar Mulia Pustaka.

Srinivasan, S.R., dan Srivastava, R.K. (2010). Creating the Futuristic Retail Experience Through Experiential Marketing: Is it Possible Quest; An Exploratory Study. Journal of Retail \& Leisure Property, 9 (3), hal. 193-199

Supranto dan Limakrisna, Nanda. (2011). Perilaku Konsumen dan Strategi Pemasaran. Jakarta: Mitra Wacana Media.

Suparyanto \& Rosad. 2015. Manajemen Pemasaran, In Media, Yogyakarta

Tjiptono, Fandi. 2008. Strategi Pemasaran. Edisi Tiga. Yogyakarta : CV. ANDI.

Tjiptono, F. (2011), Manajemen dan Strategi Merek, Seri Manajemen Merek 01. Yogyakarta: Penerbit Andi Offset

Wijaya, Bambang Sukma. 2013. Dimensi Citra Merek dalam Perspektif Komunikasi Merek. Jurnal Komunikasi Vol. 2 No. 1

Wong, F. \& Sidek, Y. 2008. Influence of brand loyalty on consumer sportwear. International Journal of Economics and Management 2(2): 221-236.

Young Hee Kim, et al. (2016). The Adoption of Mobile Payment Services for Fintech. Research India Publication, Volume 11, Number 2, 1058-1061

Zehir, C., Sahin, A., Kitapci, H. \& Ozsahin, M. 2011. The effects of brand communication and service quality in building brand loyalty through brand trust: the empirical research on global brands. International 
Strategic Management 24(1): 1218-1231.

Zeithaml,Valarie A and Bitner. (2000). Service Marketing 2nd edition : Integrating Customer Focus. New York.McGraw-Hill Inc.

Zikmund, William G., Barry J. Babin, Jon C. Carr, Mitch Griffin. 2009. Business Research Methods. Edisi 8. SouthWestern College.

\section{Appendix}

Table 6.1: The Items List Used in the study

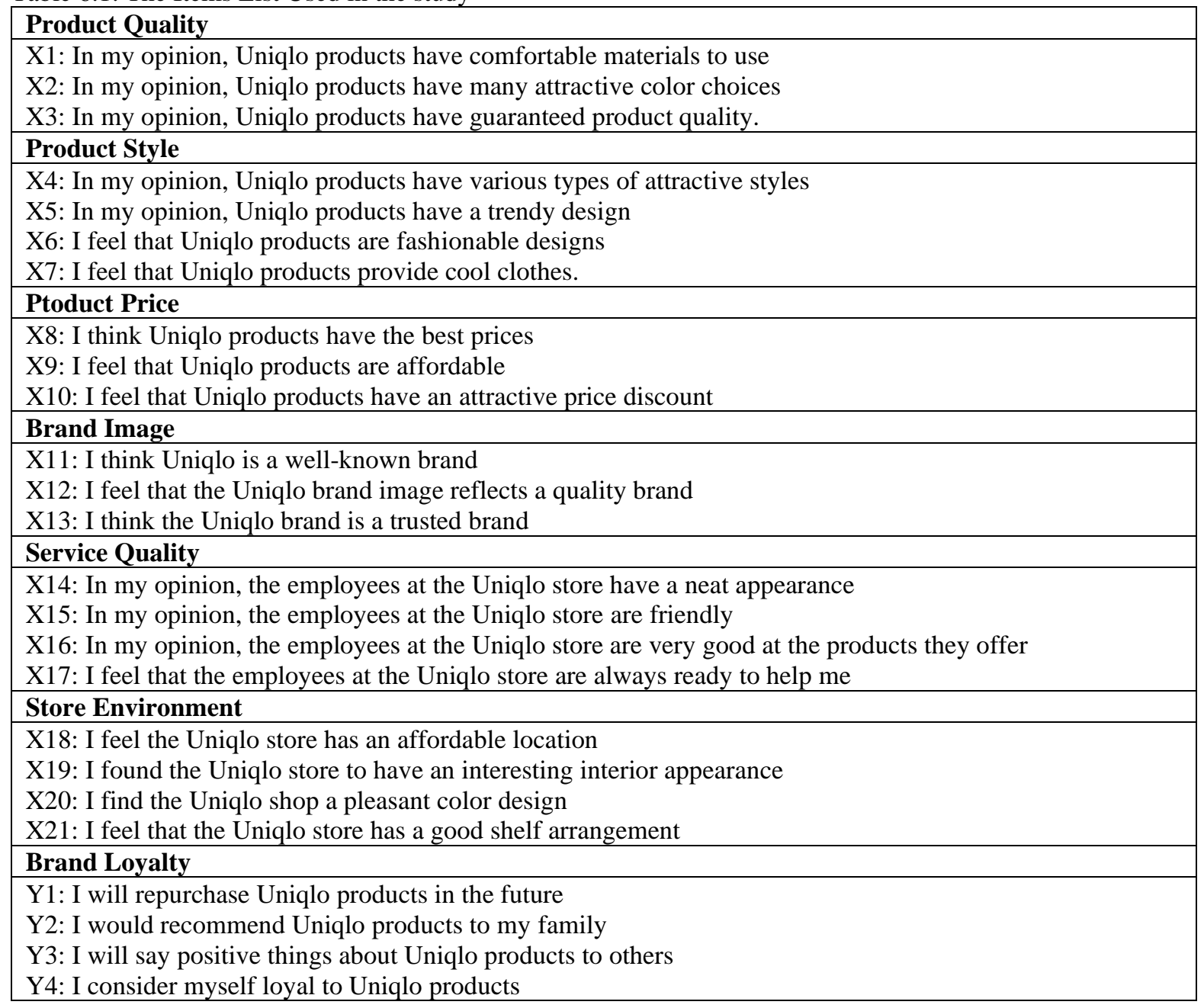

